\title{
Oxidation of benzoins to benzils in the presence of porphyrin sensitizers by air and sunlight or visible light
}

\author{
Maryam Ciyabi Hashjin • Roghayeh Ciyabi • \\ Maryam Baharloui • Nava Taherizadeh • \\ Ghaffar Hosseini
}

Received: 24 December 2012/ Accepted: 1 March 2013/Published online: 17 March 2013

(C) The Author(s) 2013. This article is published with open access at Springerlink.com

\begin{abstract}
In this work, two new aerobic routes are introduced for the oxidation of a variety of benzoins to benzils by using molecular oxygen in the presence of porphyrins as sensitizers, using white light or sunlight in acetonitrile under mild conditions. The methods have a wide range of applications, do not involve cumbersome work-up, exhibit chemoselectivity and proceed under mild reaction conditions. The resulting products are obtained in good yields in a reasonable time.
\end{abstract}

Keywords Photooxidation · Benzoin · Benzil · Visible light $\cdot$ Sunlight

\section{Introduction}

Among the important structures that are found in many bioactive compounds [1, 2], and applications in organic synthesis are 1,2-diketones [3]. 1,2-Diketones are utilized as intermediates in the synthesis of chiral ligands, pharmaceuticals, and biologically active compounds [4-6], photoinitiators [7-10], precursors of porphyrins [11-13], preparation of variety of heterocycles [14-21], and natural products [22, 23]. 1,2-Diketones are found in selective inhibitors of carboxylesterases, acid corrosion of mild steel inhibitors, and in photocurable coatings as photosensitive agents [24-26].

Because of the above-mentioned properties of 1,2-diketones, various synthetic methods have been reported by different research groups, such as direct oxidation of a-hydroxyketones by using nitric acid [27], ammonium nitrate-copper(II) acetate [28], thallium(III) nitrate [29], iodoxybenzene [30], oxone-alumina [31], bismuth(III) nitrate-copper(II) acetate [32], iron(III) nitrate [33], tert-butyl

M. Ciyabi Hashjin $(\bowtie) \cdot$ R. Ciyabi · M. Baharloui · N. Taherizadeh · G. Hosseini Department of Chemistry, Faculty of Science, Islamic Azad University, Karaj Branch, P.O. Box 31485-313, Karaj, Iran e-mail: mciyabi@gmail.com 
hydroperoxide-titanium(IV) chloride [34], sodium hydride [35], and porphyrin [36]. 1,2-Diketones have been synthesized with different reagents, such as oxidation of 1,2-diols [37, 38], oxidation of alkynes [39-49], oxidation of alkenes [50], oxidation of a-methylene ketones [51], rearrangement of a,b-epoxyketones [52-54], oxidation of vicinal dihaloalkenes [55], oxidation of epoxides [56], oxidation of 1,3-diols [57], and oxidation with molecular oxygen. They have been catalyzed by trichlorooxyvanadium [58], nickel-aluminum hydrotalcite [59], and chiral cobalt complex [60], while palladium-catalyzed oxidation of benzoins to benzils was achieved by using $\mathrm{CsOH}$ or $\mathrm{K}_{2} \mathrm{CO}_{3}$ as a base [61-63]. Porphyrins and metalloporphyrin complexes have been used in numerous biological systems [64]. Various synthetic metalloporphyrins have been studied such as the cytochrome P-450 model and as the catalyst for oxidation of alcohols, hydrocarbons and epoxidation of alkenes using molecular oxygen and various oxygen transfer reagents [65-69]. Iron porphyrins are well known, and many studies have been devoted to elucidating and using catalysts for alkane hydroxylation, oxidation of alkanes to alcohols or ketones, and oxidation of hydrocarbons [70-73]. Stochiometric amounts of a strong oxidant are needed for the generation of metalloporphyrins [74]. The photosensitized production of singlet oxygen has significance in the photooxidation of organic compounds, DNA damage, and photodynamic therapy [75-77], such that a variety of these photosensitizers have been developed and extensively studied [78-83].

\section{Experimental}

General procedure for the synthesis of porphyrins

$\mathrm{H}_{2}$ TPP (Tetraphenylpor phyrin), $\mathrm{H}_{2}$ TMP (Tetramesitylepor phyrin), $\mathrm{H}_{2}$ TPFPP (Tetra(pentafluorophenyl) porphyrin), ClFeTMP, ClFeTPP, ClFeTPFPP and ZnTMP were synthesized and purified using Lindsey's Method and metallated according to Adler [84-86]. Metallated and non-metalled sensitizers were characterized by UV-Vis and ${ }^{1} \mathrm{H}$ NMR spectra.

General procedure for the synthesis of benzoins

To a solution of adehydes $(15 \mathrm{mmol})$ in $\mathrm{EtOH}(8 \mathrm{~mL})$ was added a solution of $\mathrm{NaCN}(6.3 \mathrm{mmol})$ in $\mathrm{H}_{2} \mathrm{O}(1.5 \mathrm{~mL})$. After stirring at reflux $\left(80{ }^{\circ} \mathrm{C}\right)$ for $2 \mathrm{~h}$, the reaction mixture was cooled to room temperature, concentrated in vacuo, and extracted with $\mathrm{CH}_{2} \mathrm{Cl}_{2}$ and saturated aqueous $\mathrm{NaHCO}_{3}$. The combined organic layers were dried over $\mathrm{Na}_{2} \mathrm{SO}_{4}$ and concentrated in vacuo. The residue was purified by flash column chromatography to give benzoin substrates [87-89].

General procedure for the synthesis of benzils

The benzoins $\left(1.0 \mathrm{mmol}\right.$ ) and a $1 \mathrm{ml} \mathrm{CH}_{2} \mathrm{Cl}_{2}$ solution of the porphyrins $\left(1.0 \times 10^{-3} \mathrm{mmol}\right)$ were dissolved in $14 \mathrm{~mL}$ of $\mathrm{CH}_{3} \mathrm{CN}$ in a quartz tube. Air was bubbled through the solution and the samples were irradiated using visible light 
or sunlight for $24 \mathrm{~h}$. The solvent was removed under vacuum, and the residue was separated by column chromatography (silica gel, $n$-hexane/EtOAc, $3: 1$ ) to give the corresponding benzil.

\section{Spectral data}

\section{Benzil}

Yellow solid, Mp: $95-96{ }^{\circ} \mathrm{C} .{ }^{1} \mathrm{H}$ NMR $\left(300 \mathrm{MHz}, \mathrm{CDCl}_{3}\right): \delta: 7.50(\mathrm{t}, J=8.0 \mathrm{~Hz}$, $4 \mathrm{H}) ; 7.69$ (t, $J=7.2 \mathrm{~Hz}, 2 \mathrm{H}) ; 7.90-8.00(4 \mathrm{H}, \mathrm{m}) .{ }^{13} \mathrm{C} \mathrm{NMR}\left(75 \mathrm{MHz}, \mathrm{CDCl}_{3}\right): \delta$ : $129.0 ; 130.0 ; 133.1 ; 135.0 ; 194.7$. Anal. Calcd. for $\mathrm{C}_{14} \mathrm{H}_{10} \mathrm{O}_{2}$ : C, 79.98; $\mathrm{H}, 4.79$; found $\mathrm{C}, 79.95 ; \mathrm{H}, 4.69$.

\section{1,2-Dip-tolylethane-1,2-dione}

Yellow solid. Mp: $103-104{ }^{\circ} \mathrm{C}{ }^{1} \mathrm{H}$ NMR (300 MHz, $\left.\mathrm{CDCl}_{3}\right): \delta: 2.33(6 \mathrm{H}, \mathrm{s}) ; 7.20$ $(4 \mathrm{H}, \mathrm{d}, J=8.1 \mathrm{~Hz}) ; 7.77(4 \mathrm{H}, \mathrm{d}, J=8.1 \mathrm{~Hz}) .{ }^{13} \mathrm{C} \mathrm{NMR}\left(75 \mathrm{MHz}, \mathrm{CDCl}_{3}\right): \delta$ : $22.1 ; 129.8 ; 130.2 ; 130.8 ; 146.0 ; 194.6$. Anal. Calcd. for $\mathrm{C}_{16} \mathrm{H}_{14} \mathrm{O}_{2}: \mathrm{C}, 80.65 ; \mathrm{H}$, 5.92; found C, 80.65; H, 5.92.

\section{1,2-Bis(3-Methoxyphenyl)ethane-1,2-dione}

Yellow solid, Mp: $82{ }^{\circ} \mathrm{C} .{ }^{1} \mathrm{H}$ NMR (300 MHz, $\left.\mathrm{CDCl}_{3}\right): \delta: 3.80(6 \mathrm{H}, \mathrm{s}) ; 7.10-7.20$ $(2 \mathrm{H}, \mathrm{m}) ; 7.40(2 \mathrm{H}, \mathrm{t}, J=8.0 \mathrm{~Hz}) ; 7.45-7.50(2 \mathrm{H}, \mathrm{m}) ; 7.50-7.50(2 \mathrm{H}, \mathrm{m}) .{ }^{13} \mathrm{C} \mathrm{NMR}$ $\left(75 \mathrm{MHz}, \mathrm{CDCl}_{3}\right): \delta: 55.4 ; 113.8 ; 122.1 ; 123.3 ; 130.0 ; 134.5 ; 160.4 ; 194.0$. Anal. Calcd. for $\mathrm{C}_{16} \mathrm{H}_{14} \mathrm{O}_{4}$ : C, 71.10; H, 5.22; found $\mathrm{C}, 71.08 ; \mathrm{H}, 5.12$.

\section{1,2-Bis(4-Chlorophenyl)ethane-1,2-dione}

Yellow solid, Mp: $195-196{ }^{\circ} \mathrm{C} .{ }^{1} \mathrm{H}$ NMR $\left(300 \mathrm{MHz}, \mathrm{CDCl}_{3}\right): \delta: 7.50(4 \mathrm{H}, \mathrm{d}$, $J=8.6) ; 7.92(4 \mathrm{H}, \mathrm{d}, J=8.6) .{ }^{13} \mathrm{C} \mathrm{NMR}\left(75 \mathrm{MHz}, \mathrm{CDCl}_{3}\right): \delta: 129.7 ; 131.3$; 131.4; 142.0, 192.5. Anal. Calcd. for $\mathrm{C}_{14} \mathrm{H}_{8} \mathrm{Cl}_{2} \mathrm{O}_{2}$ : C, 60.24; $\mathrm{H}, 2.89$; found $\mathrm{C}$, $60.20 ; \mathrm{H}, 2.85$.

\section{1,2-Bis(4-Bromophenyl)ethane-1,2-dione}

Yellow solid, Mp: $224-226{ }^{\circ} \mathrm{C} .{ }^{1} \mathrm{H}$ NMR $\left(300 \mathrm{MHz}, \mathrm{CDCl}_{3}\right): \delta: 7.65(4 \mathrm{H}, \mathrm{d}$, $J=8.0 \mathrm{~Hz}) ; 7.80(4 \mathrm{H}, \mathrm{d}, J=8.0 \mathrm{~Hz}) .{ }^{13} \mathrm{C} \mathrm{NMR}\left(75 \mathrm{MHz}, \mathrm{CDCl}_{3}\right): \delta: 130.9$; 131.4; 131.7; 132.7; 192.7. Anal. Calcd. for $\mathrm{C}_{14} \mathrm{H}_{8} \mathrm{Br}_{2} \mathrm{O}_{2}$ : C, 45.69; H, 2.19; found C, 45.60; H, 2.09 .

\section{1,2-Di(Naphthalen-2-yl)ethane-1,2-dione}

Yellow solid, Mp: $156-158{ }^{\circ} \mathrm{C} .{ }^{1} \mathrm{H}$ NMR $\left(300 \mathrm{MHz}, \mathrm{CDCl}_{3}\right): \delta: 7.50-7.58(2 \mathrm{H}, \mathrm{m})$; $7.63(2 \mathrm{H}, \mathrm{m}) ; 7.86-7.97(6 \mathrm{H}, \mathrm{m}) ; 8.17(2 \mathrm{H}, \mathrm{m}) ; 8.49(2 \mathrm{H}, \mathrm{s}) .{ }^{13} \mathrm{C}$ NMR $(75 \mathrm{MHz}$, 

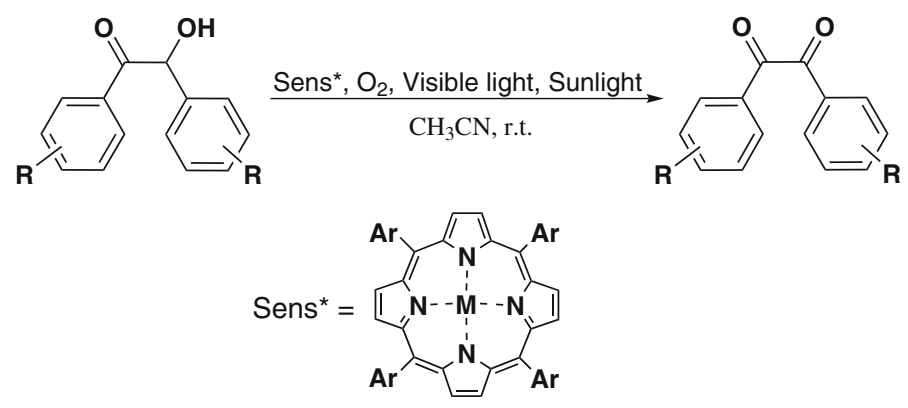

M: $\mathrm{H}$ and $\mathrm{Fe}$

Scheme 1 Oxidation of benzoins to benzils

$\left.\mathrm{CDCl}_{3}\right): \delta: 123.5 ; 127.3 ; 128.0 ; 129.2 ; 129.7 ; 130.1 ; 130.5 ; 132.4 ; 133.7 ; 136.4 ;$ 194.7. Anal. Calcd. for $\mathrm{C}_{22} \mathrm{H}_{14} \mathrm{O}_{2}$ : C, 85.14; H, 4.55; found C, 85.04; H, 4.45.

\section{Results and discussion}

Many investigations for the preparation of benzils such as the reaction of oxalyl chloride with organostannanes, oxidation of alkynes, aldehyde condensation, and oxidation of alcohols have been documented. In view of significant drawbacks, such as the use of toxic and expensive reagents, high temperature, stoichiometric amounts of reagents, and low yield of these methods [90-94], a more efficient catalytic system is in high demand.

In continuation, here we would like to report a highly efficient catalytic system for the aerobic oxidation of benzoin derivatives using porphyrins as catalyst, which can be smoothly oxidized to corresponding benzils. Photooxygenation was performed in solutions of acetonitrile under visible light or sunlight in the presence of porphyrins under $1 \mathrm{~atm}$ pressure of air at room temperature (Scheme 1).

The catalytic activity of different metalloporphyrins and structurally different free base porphyrins for the oxidation of benzoins to benzils compounds by molecular oxygen were investigated by using 2-hydroxy-1,2-diphenylethanone as a model substrate. The engaged metals for the oxidation reactions were $\mathrm{Fe}, \mathrm{Mn}$, and $\mathrm{Zn}$, and ( $\left.\mathrm{H}_{2} \mathrm{TPP}\right),\left(\mathrm{H}_{2} \mathrm{TMP}\right)$, and $\left(\mathrm{H}_{2} \mathrm{TPFPP}\right)$ were employed to cover different electronic properties. The results are summarized in Table 1. The oxidation of 2-hydroxy-1,2diphenylethanone catalyzed by these catalysts produced benzil as the product. The catalytic activity of metalloporphyrins for oxidation appears to be dependent on the nature of the central ions. CIFeTMP porphyrin showed the best activity among the three simple structure metalloporphyrin catalysts, and presented an excellent catalytic performance for the oxidation of 2-hydroxy-1,2-diphenylethanone in mild conditions. The catalytic activation of the four metalloporphyrins were in the sequence: ClFeTMP $>$ ClMnTMP $>\mathrm{Mn}$ (TDCPP)Cl $>\mathrm{Mn}$ (TDFPP)Cl $>\mathrm{Mn}$ (TPFPP)Cl $=$ ZnTMP. The order for reactivity of the free base ligands was $\mathrm{H}_{2}$ TMP $>\mathrm{H}_{2}$ TPP $>\mathrm{H}_{2}$ TPFPP, showing that electron donation to the porphyrin rings facilitates the conversion of 
Table 1 Effect of porphyrins on the photooxidation of 2-hydroxy-1,2-diphenylethanone to benzil

\begin{tabular}{lll}
\hline Entry & Catalyst & Yield of benzil (\%) \\
\hline 1 & $\mathrm{H}_{2}$ TMP & 90 \\
2 & $\mathrm{H}_{2}$ TPP & 55 \\
3 & $\mathrm{H}_{2}$ TPFPP & Trace \\
4 & ClFeTMP & 87 \\
5 & ClFeTPP & 22 \\
6 & ClFeTPFPP & 23 \\
7 & ClMnTMP & 60 \\
8 & Mn(TDCPP)Cl & 10 \\
9 & Mn(TDFP)Cl & 5 \\
10 & Mn(TPFPP)Cl & Trace \\
11 & ZnTMP & Trace \\
12 & - & 0 \\
\hline $1 \times 10^{-6}$ m & - & .
\end{tabular}

$1 \times 10^{-6}$ mol porphyrins, $1 \times 10^{-3} \mathrm{~mol}$ 2-hydroxy-1,2-diphenylethanone after $24 \mathrm{~h}$ irradiation, air (1 atm) and fluorescent circular lamp, in the $\mathrm{CH}_{3} \mathrm{CN}$ solvent

2-hydroxy-1,2-diphenylethanone in our reaction condition. Safari and et al. reported oxidations of alcohols with paramagnetic metals and free base ligands in high yields (Fe and Mn) [95, 96].

In order to obtain the best conditions, various solvents were used for the aerobic oxidation of 2-hydroxy-1,2-diphenylethanone, and the results are summarized in Table 2. Acetonitrile is a good solvent for oxidation reactions, since it is relatively inert toward oxidation, and its tendency toward coordination and interaction with coordination compound is low. In addition, acetonitrile is usually polar enough to dissolve the substrates, products, and the catalyst. For the $m$-THPC $(5,10,15,20$ tetra( $m$-hydroxyphenyl)chlorin) sensitizer, the singlet oxygen lifetime in DMSO is $19 \mu$ s compared to $65 \mu$ s in $\mathrm{CH}_{3} \mathrm{CN}$ [97]. According to the literature, DMSO, $\mathrm{H}_{2} \mathrm{O}$, $\mathrm{CH}_{3} \mathrm{OH}, \mathrm{C}_{2} \mathrm{H}_{5} \mathrm{OH}$ and DMF are singlet oxygen quenchers [98-100]. In addition, it is confirmed that the lifetime of ${ }^{1} \mathrm{O}_{2}$ in acetonitrile is high. The main mechanism which takes place in our reaction conditions may be the generation of singlet oxygens and their reaction with the substrates. Further evidence for a ${ }^{1} \mathrm{O}_{2}$ mechanism was obtained by performing the photooxygenation in the presence of $\mathrm{N}_{3}{ }^{-}$, which is known as a singlet oxygen scavenger [95, 96, 101]. Entry 4 in Table 2 shows that the yield of free base porphyrin was considerably reduced under these conditions. In the presence of $\mathrm{N}_{3}{ }^{-}$, degradation of the porphyrin sensitizers was also inhibited.

The effect of light sources on the aerobic oxidation of 2-hydroxy-1,2diphenylethanone to benzil catalyzed by $\mathrm{H}_{2}$ TMP and CIFeTMP was investigated As shown in Table 3, it seems that the conversion of 2-hydroxy-1,2-diphenylethanone was closely related with sunlight or white light, However, the reaction rate is considerably increased with the UV light.

It occurred to us that this reaction might proceed under solar irradiation because the spectral distribution curves of a fluorescent lamp and visible light were similar 
Table 2 Effect of solvent on the photooxidation of 2-hydroxy-1,2-diphenylethanone to benzil

\begin{tabular}{|c|c|c|c|}
\hline \multirow[t]{2}{*}{ Entry } & \multirow[t]{2}{*}{ Solvent } & \multicolumn{2}{|c|}{ Yield (\%) } \\
\hline & & $\mathrm{H}_{2} \mathrm{TMP}$ & ClFeTMP \\
\hline 1 & Acetonitrile & 90 & 87 \\
\hline 2 & Dimethyl formamide & Trace & Trace \\
\hline 3 & Dimethyl sulfoxide & Trace & Trace \\
\hline 4 & $\mathrm{NaN}_{3} / \mathrm{Na}_{2} \mathrm{SO}_{3} /$ acetonitrile & - & 85 \\
\hline 5 & $\mathrm{H}_{2} \mathrm{O}$ & Trace & Trace \\
\hline 6 & $\mathrm{CH}_{3} \mathrm{OH}$ & Trace & Trace \\
\hline 7 & $\mathrm{C}_{2} \mathrm{H}_{5} \mathrm{OH}$ & Trace & Trace \\
\hline
\end{tabular}

$1 \times 10^{-6}$ mol porphyrins, $1 \times 10^{-3} \mathrm{~mol}$ 2-hydroxy-1,2-diphenylethanone after $24 \mathrm{~h}$ irradiation

Table 3 Effect of light on the photooxidation of 2-hydroxy-1,2-diphenylethanone

\begin{tabular}{lllll}
\hline Entry & Source & Time $(\mathrm{h})$ & Yield for $\mathrm{H}_{2}$ TMP $(\%)$ & Yield for CIFeTMP (\%) \\
\hline 1 & White light & 24 & 90 & 87 \\
2 & Sunlight & 20 & 90 & 87 \\
\hline
\end{tabular}

$1 \times 10^{-6}$ mol porphyrins, $1.0 \times 10^{-3} \mathrm{~mol}$ 2-hydroxy-1,2-diphenylethanone

to that of sunlight. Furthermore, in accordance with the concept of "green chemistry", solar radiation is an infinite source of clean energy. In continuation, we checked the generality of the method, in which a variety of benzoins were oxidized to benzil compounds with $\mathrm{H}_{2}$ TMP and ClFeTMP in moderate to excellent yields at room temperature with sunlight irradiation. The reactions were performed in a tube without any particular precautions. As shown in Table 4, this catalytic system was applicable to a wide range of benzoin substrates.

A possible mechanism for the formation of products with $\mathrm{H}_{2} \mathrm{TMP}$ and ClFeTMP porphyrin is shown in Scheme 2. Thus, in the presence of $\mathrm{H}_{2}$ TMP formation singlet oxygen, there may be a new photochemical pathway that involves the overall insertion of molecular oxygen into the $\mathrm{C}-\mathrm{H}$ bond of the alcohols $\mathbf{1}$ to form benzoins 2. Furthermore, independent photolysis of 2-hydroperoxy-2-hydroxy-1,2-diphenylethanone $\mathbf{2}$ in $\mathrm{CH}_{3} \mathrm{CN}$ results in the formation of $\mathbf{3}$, which is the only product [95, 96, 102]. Compound $\mathbf{3}$ decomposes further to the final product $\mathbf{4}$ and hydrogen peroxide which is a by-product. In the presence of ClFeTMP as a catalyst and oxygen, formation of intermediate $\mathbf{5}$ from photo-homolysis of $\mathbf{5}$ was formed through the reaction of Fe(II)TMP. The existance of Iron (II) comes from the homolysis of ClFeTMP [80, 95, 96, 103]. Iron(IV)-oxo intermediates activate alcohols exclusively by $\mathrm{H}$-atom abstraction from the $\mathrm{R}-\mathrm{CH}$ group of alcohol and result in the formation of 7. Formation of $\mathbf{4}$ possibly occurred by a dual hydrogen abstraction mechanism as previously proposed $[95,96,103-105]$. Safari et al. have proven these mechanisms $[95,96]$. 


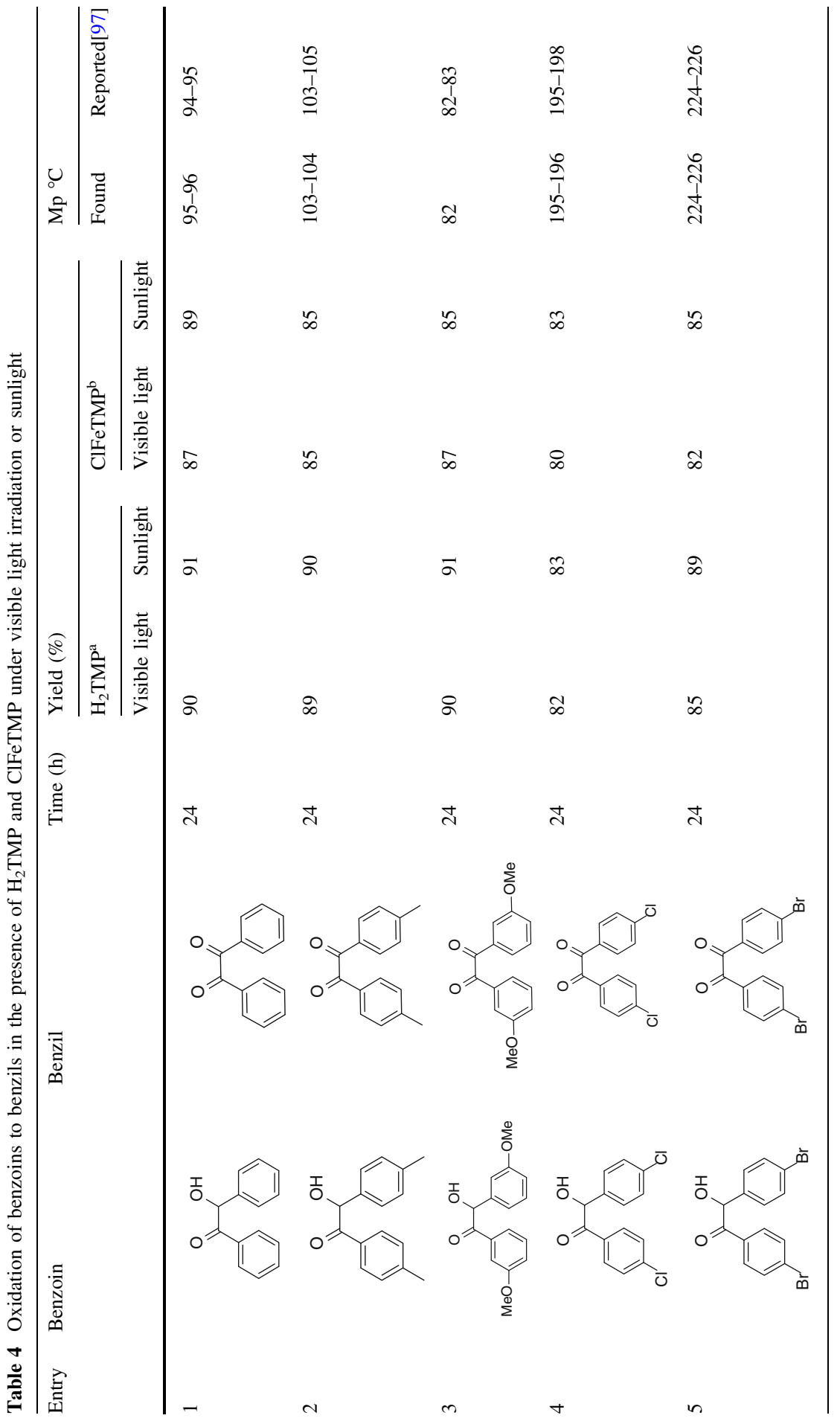




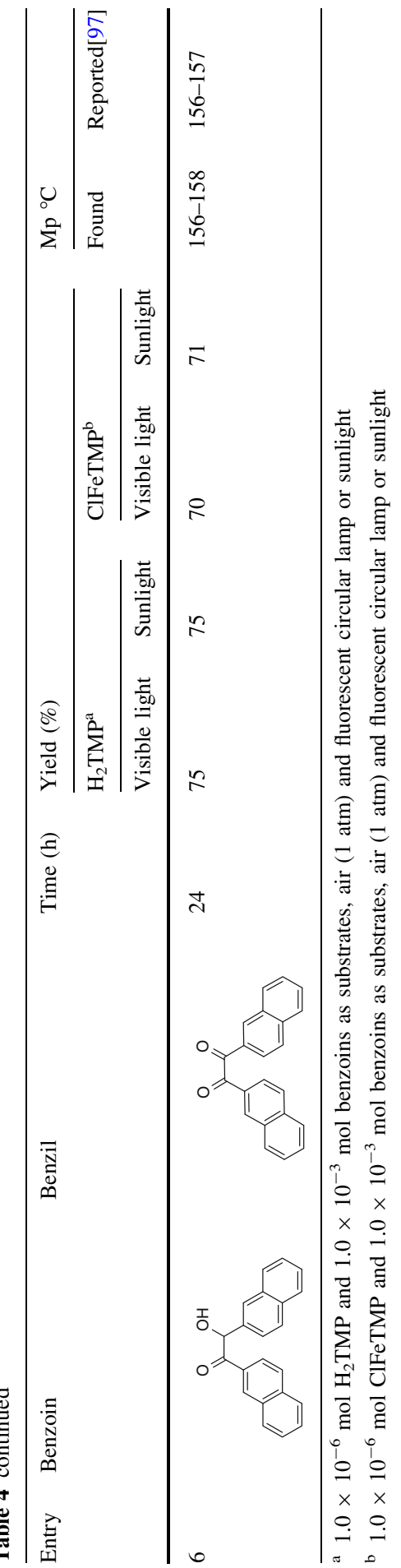




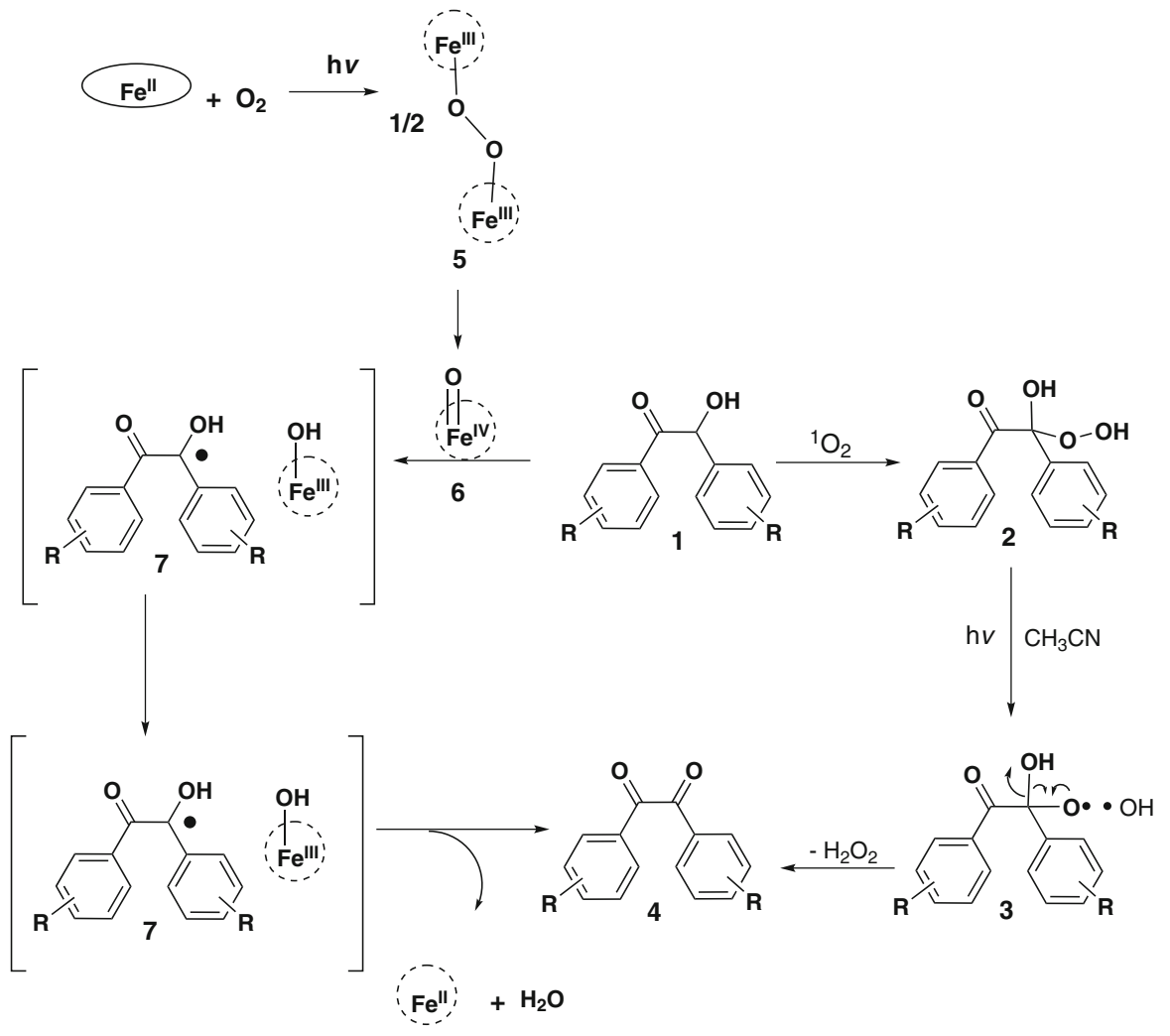

Scheme 2 Proposed mechanism

\section{Conclusion}

We have developed a very simple and efficient aerobic photooxidation oxidation reaction for the conversion of benzoins to benzils using a catalytic amount of a nonmetallated and metallated porphyrins in the presence of visible light irradiation of a fluorescent lamp or sunlight and air in $\mathrm{CH}_{3} \mathrm{CN}$. This novel method is thought to be convenient, green in view of the use of the catalyst, and environmentally friendly. This method is of great value from the perspectives green chemistry and organic synthesis due to its use of inexpensive and harmless visible light irradiated from a general purpose fluorescent lamp or sunlight, and molecular oxygen as terminal oxidant. Further application of this photooxidation to other reactions is now in progress in our laboratory.

Acknowledgment We gratefully acknowledge financial support from the Research Council of Islamic Azad University of Karaj.

Open Access This article is distributed under the terms of the Creative Commons Attribution License which permits any use, distribution, and reproduction in any medium, provided the original author(s) and the source are credited. 


\section{References}

1. K.C. Nicolaou, D.L.F. Gray, J. Tae, J. Am. Chem. Soc. 126, 613 (2004)

2. M.R. Angelstro, S. Mehdi, J.P. Burkhart, N.P. Peet, P. Bey, J. Med. Chem. 33, 11 (1990)

3. E.S. Krongauz, Russ. Chem. Rev. 46, 59 (1977)

4. E.J. Corey, D.H. Lee, S. Sarshar, Tetrahedron Asymmetry 6, 3 (1995)

5. A. Ryoda, N. Yajima, T. Haga, T. Kumamoto, W. Nakanishi, M. Kawahata, K. Yamaguchi, T. Ishikawa, J. Org. Chem. 73, 133 (2008)

6. L.R. Hillis, R.C. Ronald, J. Org. Chem. 50, 470 (1985)

7. D.H.S. Yu, J.M. Torkelson, Macromolecules 21, 852 (1988)

8. F. Catalina, C. Peinado, M. Blanco, A. Alonso, N.S.J. Allen, Photochem. Photobiol. A 131, 141 (2000)

9. P.K. Roy, P. Surekha, C. Rajagopal, S.N. Chatterjee, V. Choudhary, Polym. Degrad. Stab. 90, 577 (2005)

10. Z. Szablan, T.M. Lovestead, T.P. Davis, M.H. Stenzel, C. Barner-Kowollik, Macromolecules 40, 26 (2007)

11. M. Friedman, J. Org. Chem. 30, 859 (1965)

12. K.M. Kadish, E. Van Caemelbecke, F. DSouza, M. Lin, D.J. Nurco, C.J. Medforth, T.P. Forsyth, B. Krattinger, K.M. Smith, S. Fukuzumi, I. Nakanishi, J. Shelnutt, A. Inorg. Chem. 38, 2188 (1999)

13. G. Du, G.A. Mirafzal, L.K. Woo, Organometallics 23, 4230 (2004)

14. A.S. Kiselyov, Tetrahedron Lett. 36, 493 (1995)

15. M.H. Nantz, D.A. Lee, D.M. Bender, A.H. Roohi, J. Org. Chem. 57, 6653 (1992)

16. E.C. Taylor, J.E.L.G. Macor, J. French, Org. Chem. 56, 1807 (1991)

17. I. Flament, M. Stoll, Helv. Chim. Acta 50, 1754 (1967)

18. T.E. Barta, M.A. Stealey, P.W. Collins, R.M. Weier, Bioorg. Med. Chem. Lett. 8, 3443 (1998)

19. Z. Zhao, D.D. Wisnoski, S.E. Wolkenberg, W.H. Leister, Y. Wang, C.W. Lindsley, Tetrahedron Lett. 45, 4873 (2004)

20. I. Held, S.J. Xu, H. Zipse, Synthesis 8, 1185 (2007)

21. F. Rong, S. Chow, S. Yan, G. Larson, Z. Hong, Wu, J. Bioorg. Med. Chem. Lett. 17, 1663 (2007)

22. W.G. Dauben, K.L. Lorenz, D.W. Dean, G. Shapiro, I. Farkas, Tetrahedron Lett. 39, 7079 (1998)

23. S. Danishefsky, R. Zamboni, M. Kahn, S.J. Etheredge, J. Am. Chem. Soc. 103, 3460 (1981)

24. J.L. Hyatt, V. Stacy, R.M. Wadkins, K.J.P. Yoon, M. Wierdl, C.C. Edwards, M. Zeller, A.D. Hunter, M.K. Danks, G. Crundwell, P.M. Potter, J. Med. Chem. 48, 5543 (2005)

25. B.I. Ita, O.E. Offiong, Mater. Chem. Phys. 70, 330 (2001)

26. M.R. Ams, C.S. Wilcox, J. Am. Chem. Soc. 129, 3966 (2007)

27. N. Zinin, Ann. Chem. Pharm. 34, 186 (1840)

28. M. Weiss, M. Appel, J. Am. Chem. Soc. 70, 3666 (1948)

29. A. McKillop, B.P. Swann, M.E. Ford, E.C. Taylor, J. Am. Chem. Soc. 95, 3641 (1973)

30. S. Ranganathan, D. Ranganathan, P.V. Ramachandran, Tetrahedron 40, 3145 (1984)

31. M. Hirano, M. Oose, T. Morimoto, Bull. Chem. Soc. Jpn. 64, 1046 (1991)

32. S.A. Tymonko, B.A. Nattier, R.S. Mohan, Tetrahedron Lett. 40, 7657 (1999)

33. V.V. Namboodiri, V. Polshettiwar, R.S. Varma, Tetrahedron Lett. 48, 8839 (2007)

34. C.T. Shei, H.L. Chien, K. Sung, Synlett 7, 1021 (2008)

35. C. Joo, S. Kang, S.M. Kim, H. Han, J.W. Yang, Tetrahedron Lett. 51, 6006 (2010)

36. G. Du, L.K. Woo, J. Porphyrins Phthalocyanines 9, 206 (2005)

37. S.L. Jain, V.B. Sharma, B. Sain, Tetrahedron Lett. 45, 1233 (2004)

38. J.M. Khurana, B.M. Kandpal, Tetrahedron Lett. 44, 4909 (2003)

39. J.N. Moorthy, N. Singhal, K. Senapati, Tetrahedron Lett. 47, 1757 (2006)

40. R. Zibuck, D. Seebach, Helv. Chim. Acta 71, 237 (1988)

41. H. Gopal, A.J. Gordon, Tetrahedron Lett. 12, 2941 (1971)

42. D.G. Lee, V.S. Chang, J. Org. Chem. 44, 2726 (1979)

43. S. Wolfe, W.R. Pilgrim, T.F. Garrard, P. Chamberlain, Can. J. Chem. 49, 1099 (1971)

44. A. McKillop, O.H. Oldenziel, B.P. Swann, E.C. Taylor, R.L. Robey, J. Am. Chem. Soc. 95,1296 (1973)

45. W. Ren, Y. Xia, S. Ji, Y. Zhang, X. Wan, J. Zhao, Org. Lett. 11, 1841 (2009)

46. K. J. Tan, U. Wille, Chem. Commun. 6239 (2008)

47. M. Niu, H. Fu, Y. Jiang, Y. Zhao, Synthesis 18, 2879 (2008) 
48. S. Dayan, I. Ben-David, S. Rozen, J. Org. Chem. 65, 8816 (2000)

49. Y. Sawaki, H. Inoue, Y. Ogata, Bull. Chem. Soc. Jpn. 56, 1133 (1983)

50. Yusubov, V.D. Filimonov, V.P. Vasilyeva, Synthesis 10, 1234 (1995)

51. N. Rabjohn, Org. React. 24, 261 (1976)

52. C.L. Chang, M.P. Kumar, R.S. Liu, J. Org. Chem. 69, 2793 (2004)

53. T.B. Rao, J.M. Rao, Synth. Commun. 23, 1527 (1993)

54. K. Suda, K. Baba, S. Nakajima, T. Takanami, Chem. Commun. 2570 (2002)

55. F.A. Khan, B. Prabhudas, J. Dash, N. Sahu, J. Am. Chem. Soc. 122, 9558 (2000)

56. S. Antoniotti, E. Dunach, Chem. Commun. 2566 (2001)

57. J.S. Yadav, S.K. Biswas, R. Srinivas, Synthesis 24, 4237 (2006)

58. M. Kirihara, Y. Ochiai, S. Takizawa, H. Takahata, H. Nemoto, Chem. Commun. 1387 (1999)

59. B.M. Choudary, M.L. Kantam, A. Rahman, C.V. Reddy, K.K. Rao, Angew. Chem. Int. Ed. 40, 763 (2001)

60. S.K. Alamsetti, P. Muthupandi, G. Sekar, Chem. Eur. J. 15, 5424 (2009)

61. C. Qin, J. Chen, H. Wu, J. Cheng, Q. Zhang, B. Zuo, W. Su, J. Ding, Tetrahedron Lett. 49, 1884 (2008)

62. W. Zhang, M. Liu, H. Wu, J. Ding, J. Cheng, Tetrahedron Lett. 49, 5336 (2008)

63. Q. Zhang, C.M. Xu, J.X. Chen, X.-L. Xu, J.C. Ding, H.Y. Wu, Appl. Organomet. Chem. 23, 524 (2009)

64. G.J. Abhilash, J. Bhuyan, P. Singh, S. Maji, K. Pal, S. Sarkar, Inorg. Chem. 48, 1790 (2009)

65. G.J. Abhilash, J. Bhuyan, P. Singh, S. Maji, K. Pal, S. Sarkar, Inorg. Chem. 48, 1790 (2009)

66. M. Haranaka, A. Hara, W. Ando, T. Akasaka, Tetrahedron Lett. 50, 3585 (2009)

67. G. Huang, S.Y. Liu, Y.A. Guo, A. Wang, J. Luo, C.C. Cai, Appl. Catal. A 350, 173 (2009)

68. M. Moghadam, V. Mirkhani, S. Tangestaninejad, I. Mohammadpoor-Baltork, H. kargar, Molecular Catalysis A 288, 116 (2008)

69. M. Moghadam, S. Tangestaninejad, V. Mirkhani, I. Mohammadpoor-Baltork, A.A. Abbasi-Larki, Applied Catalysis A 349, 177 (2008)

70. A.R. Han, Y.J. Jeong, Y. Kang, J.Y. Lee, M.S. Seo, W. Nam, Chem. Commun. 9, 1076 (2008)

71. J.E.L. Ellis, Coord. Chem. Rev. 105, 181 (1990)

72. A. Maldotti, C. Bartocci, G. Varani, A. Molinari, Inorg. Chem. 35, 1126 (1996)

73. H.R. Khavasi, N. Safari, J. Mol. Catal. A. 220, 127 (2004)

74. V.N. Korotchenko, K. Severin, M.R. Gagn, Org. Biomol. Chem. 6, 1961 (2008)

75. M.C. Derosa, R.J. Crutchley, Coord. Chem. Rev. 351, 233 (2002)

76. A. Greer, Acc. Chem. Res. 39, 797 (2006)

77. M. Hajimohammadi, F. Bahadoran, S.S.H. Davarani, N. Safari, React. Kinet. Mech. Catal. 99, 243 (2010)

78. R.W. Redmond, J.N. Gamlin, Photochem. Photobiol. 70, 391 (1999)

79. R. Bonnett, Chem. Soc. Rev. 24, 19 (1995)

80. L. Weber, R. Hommel, J. Behling, G. Haufe, H. Hennig, J. Am. Chem. Soc. 116, 2400 (1994)

81. R.K. Pandey, G. Zheng, in The Porphyrin Handbook, ed. by K.M. Kadish, K.M. Smith, R. Guilard (Academic Press, New York, 2000), p. 157

82. S.K. Pushpan, S. Venkatraman, V.G. Anand, J. Sankar, D. Parmeswaran, S. Ganesan, T.K. Chandrashekar, Curr. Med. Chem. Anticancer Agents. 2, 187 (2002)

83. E.S. Nyman, P.H. Hynninen, J. Photochem. Photobiol. B 73, 1 (2004)

84. J.S. Lindsey, R.W. Wagner, J. Org. Chem. 54, 828 (1989)

85. J. Adler, Inorg. Nucl. Chem. 32, 2443 (1970)

86. B. Boens, P.A. Faugeras, J. Vergnaud, R. Lucas, K. Teste, R. Zerrouki, Tetrahedron 66, 1994 (2010)

87. P. Singh, A. Mittal, S. Kumar, Bioorg. Med. Chem. 15, 3990 (2007)

88. P. Hoyos, G. Sansottera, M. Fernández, F. Molinari, J.V. Sinisterra, A.R. Alcantara, Tetrahedron 64, 7929 (2008)

89. Y. Shimakawa, T. Morikawa, S. Sakaguchi, Tetrahedron Lett. 51, 1786 (2010)

90. T. Kashiwabara, M. Tanaka, J. Org. Chem. 74, 3958 (2009)

91. A. Giraud, O. Provot, J. Franç, O. Peyrat, M. Alami, J.D. Brion, Tetrahedron 62, 7667 (2006)

92. Y. Shimakawa, T. Morikawa, S. Sakaguchi, Tetrahedron Lett. 51, 1786 (2010)

93. C. Joo, S. Kang, S.M. Kim, H. Han, J.W. Yang, Tetrahedron Lett. 51, 6006 (2010)

94. J.M. Khurana, B.M. Kandpal, Tetrahedron Lett. 44, 4909 (2003)

95. M. Hajimohammadi, N. Safari, H. Mofakham, F. Deyhimi, Green Chem. 13, 991 (2011)

96. M. Hajimohammadi, N. Safari, H. Mofakham, A. Shaabani, Tetrahedron Lett. 51, 4061 (2010) 
97. Y. Chen, S. Xu, L. Li, M. Zhang, J. Shen, T. Shen, Dye. Pigment. 51, 63 (2001)

98. I. Kruk, A.E. Hassan, T. Michalska, K. Ichszteld, K. Kubasik-Kladna, S. Olgen, Luminescence 22, 379 (2007)

99. A. Ogunsipe, J.Y. Chen, T. Nyokong, New J. Chem. 28, 822 (2004)

100. S. He, L. Jiang, B. Wu, Y. Pan, C. Sun, Biochem. Biophys. Res. Commun. 379, 283 (2009)

101. J.R. Harbour, S.L. Issler, J. Am. Chem. Soc. 104, 903 (1982)

102. P. Wan, S. Muralidharaina, I. Cauley, C.A. Babbage, Can. J. Chem. 65, 1775 (1987)

103. W. Nam, Acc. Chem. Res. 40, 522 (2007)

104. Y.-M. Lee, S. Hong, Y. Morimoto, W. Shin, S. Fukuzumi, W.J. Nam, Am. Chem. Soc. 132, 10668 (2010)

105. N.Y. Oh, Y. Suh, M.J. Park, M.S. Seo, J. Kim, W. Nam, Angew. Chem. Int. Ed. 117, 4307 (2005) 